\section{Women and Literacy}

Prepared by Marcela Ballara

Zed Books: London and New Jersey 1992, ISBN 1856499817 , £9.95 Pbk, ISBN 1856499809 , £29.95 Hbk

Women, and particularly rural women, are a substantial majority among the world's illiterates, though inconsistencies of definition and measurement make it impossible to say by how much. There are, in addition, either demonstrable or probable correlations between women's illiteracy, their poverty, their absence from waged work and their exclusion from formal decisionmaking structures. Women and Literacy delineates a cause: is it the same cause in all circumstances, in North and South? Who intervenes to educate women, why, and what are the results?

I regret that this book disappoints as an exploration of these questions, and since I respond to the exhortatory passion with which Marcela Ballara writes, I want to say respectfully why. At the root of the matter is that she has accepted an impossible brief. The book arises out of a collaboration between Zed Books and UNESCO, as part of a series on women and development. It is only 90 pages long, including annexes, bibliography (very useful) and index. Its stated aims number eight, any one of them probably a book-length agenda. The collaboration with UNESCO makes it difficult to evaluate the contribution of that key player in the global bureaucracy of literacy - indeed there is little said about agencies and promoters of literacy and how their projects may differ.

There is a risk of further overload in that the book addresses women's literacy in both North and South. I understand the wish not to reduce illiteracy to a problem of 'underdevelopment', given that industrialized countries have identified a core of people whose literacy is not equal to the demands of a range of social practices. 'Functional literacy' is an elastic and relative term: but this should not gloss over the differences between relative illiteracy in societies with extended compulsory education and a universal assumption of some literate performance, and relative illiteracy in societies where initial education is not universal or not very long, and where difficulty in learning may be associated with the lack of events and situations in which to use a tentative literacy. If women are disproportionate among 'illiterates' at both extremes and between them, and in the variety of relationships to work, family, religion, citizenship and power that such a span might cover, we need explanations. What Ballara risks producing instead is conflations across difference.

She does acknowledge at various points that women's situations need disaggregating and treating specifically, but this does not become an informing principle of the writing. Instead: 'Some religious traditions may restrict women's activities to domestic tasks, stressing their role as mothers, which limits their access to education. Lack of self-confidence, timidity, submissiveness to male authority, as well as isolation and age differences between participants, are also limiting factors for women's participation in education.' This cries out for development, contexting and making distinctions: they don't come fully enough. Clearly there was no room for substantial case studies, but something closer to that is needed.

It is regrettable that her own expertise, arising from work in Turkey and Cape Verde in UNESCOand UNICEF-funded projects, is modestly allowed only equal weight to material she is using at second hand. I found myself listening to different voices: where Ballara summarizes, she does so almost too faithfully, and without critical distance: she cites a study of the effects of education on productivity in 
agriculture 'in a number of developing countries. This study concluded that four years of primary education ... increased productivity by 7.4 per cent, with additional benefits in the form of increased modernization of agriculture. Production incentives, marketing facilities, distribution of seeds and fertilizers and rural extension programmes are also important.' How uniform were the results in different countries? What changes in agricultural practice were available to be made? What were men and women doing (before and after) and learning? Over what span of measurement was that precise 7.4 per cent arrived at? Given the other factors listed, how did the study isolate the effect of education?

A danger arising from the passion for literacy is to cast it not only as a tool for change but as a necessity prior to other change: the learning skill without which there can be no other learning. The outcomes of learning are more plural than that: motivation, attitude change, the capacity to organize, new practical skills, don't correspond to steps on a literacy staircase. Another difficulty for this reader comes with the concentration on women's situation almost to the exclusion of men: recognizing women's actual and potential contribution to social organization, agriculture, the environment, supporting their children's education, should not slide into saddling them with the whole responsibility.

Marcela Ballara ends the book with some notes for discussion and self-education for groups striving for good practice. They point to some of the basic difficulties about cause and effect, and open up space for critical thinking the rest of the book has not found room for: "The decrease in job opportunities for women and girls in the formal sector; and increased labour in the informal sector, stem from various factors. Can you list and discuss them? Explain the effects of the economic crisis.' Can we start again there, please - and also with other questions about context and rationale which this section offers. We certainly need to work on literacy and labour markets in the industrialized countries, where functional literacy has been put firmly on the post-Fordist training agenda, while, in the case of the UK, we have set up a neat split between 'Basic skills at the workplace' and 'Family literacy'.

\section{Sue Gardener}

\section{When Our Ship Comes In - Black Women Talk}

\section{Chapeltown Black Women Writers' Group \\ Yorkshire Art Circus: West Yorkshire 1992, ISBN 094778083 1, £6.50 Pbk}

Chapeltown Black Womens' group (in Leeds, Northern England) was formed in November 1991 to provide a meeting point for AfricanCaribbean women to talk and write together. The group meets at Roseville, an adult education centre and this is their first project, which aims to "honour and acknowledge the presence, resistance and survival of the older Caribbean woman'. (Introduction: 5) Nine West Indian women (Joyce Bernard, Carol and Fay Comrie, Elaine Davis, Agnes Hinds, Katie Stewart, Odessa Stoute, Georgina Webbe, and Jean White) have written of their experience of the last thirty years in Leeds, sharing their thoughts, feelings and opinions in their own distinctive styles.

This small but generous book goes some way to painting a picture of the everyday and common-sense understanding this first generation of migrants makes of their lives in England. In seven sections the group provides mainly personal accounts and poetry on a variety of topics. Also 